\title{
Heterogeneity in the Basic Membrane Properties of Postnatal Gonadotropin-Releasing Hormone Neurons in the Mouse
}

\author{
Joan A. Sim, Michael J. Skynner, and Allan E. Herbison \\ Laboratory of Neuroendocrinology, The Babraham Institute, Cambridge CB2 4AT, United Kingdom
}

The electrophysiological characteristics of unmodified, postnatal gonadotropin-releasing hormone $(\mathrm{GnRH})$ neurons in the female mouse were studied using whole-cell recordings and single-cell RT-PCR methodology. The GnRH neurons of adult animals fired action potentials and exhibited distinguishable voltage-current relationships in response to hyperpolarizing and depolarizing current injections. On the basis of their patterns of inward rectification, rebound depolarization, and ability to fire repetitively, $\mathrm{GnRH}$ neurons in intact adult females were categorized into four cell types (type I, 48\%; type II, 36\%; type III, 11\%; type IV, 5\%). The GnRH neurons of juvenile animals (15-22 d) exhibited passive membrane properties similar to those of adult GnRH neurons, although only type I (61\%) and type II (7\%) cells were encountered, in addition to a group of "silent-type" $\mathrm{GnRH}$ neurons (32\%) that were unable to fire action potentials. A massive, action potential-independent tonic GABA input, signal- ing through the $\mathrm{GABA}_{\mathrm{A}}$ receptor, was present at all ages. Afterdepolarization and afterhyperpolarization potentials (AHPs) were observed after single action potentials in subpopulations of each $\mathrm{GnRH}$ neuron type. Tetrodotoxin (TTX)-independent calcium spikes, as well as AHPs, were encountered more frequently in juvenile $\mathrm{GnRH}$ neurons compared with adults. These observations demonstrate the existence of multiple layers of functional heterogeneity in the firing properties of $\mathrm{GnRH}$ neurons. Together with pharmacological experiments, these findings suggest that potassium and calcium channels are expressed in a differential manner within the $\mathrm{GnRH}$ phenotype. This heterogeneity occurs in a development-specific manner and may underlie the functional maturation and diversity of this unique neuronal phenotype.

Key words: calcium channels; GnRH; $L H R H ; G A B A_{A}$; receptor; patch-clamp electrophysiology; potassium channels; puberty
The gonadotropin-releasing hormone $(\mathrm{GnRH})$ neurons are thought to represent a functionally discrete population of cells that control mammalian fertility by regulating the secretion of gonadotropic hormones from the pituitary gland. Despite their clear importance in the survival of mammalian species, relatively little is known about their molecular properties and even less information is available on their electrophysiological characteristics. This has resulted principally from the scattered distribution of the GnRH cell bodies within the basal forebrain, which has made their investigation in situ extremely difficult. Because these neurons secrete GnRH in a pulsatile manner (Levine et al., 1991), important questions exist about the basic membrane properties of these neurons, as well as the mechanisms of pulsatility and synchronicity within the GnRH neuronal network as a whole. It also remains unclear whether the GnRH population is indeed a functionally homogenous population, as is assumed for other neuroendocrine phenotypes.

Recent studies using GnRH promoter transgenics to target the GnRH phenotype in the mouse (Pape et al., 1999; Skynner et al., 1999a; Spergel et al., 1999; Simonian et al., 2000; Suter et al., 2000) have provided one avenue through which the molecular and electrical nature of GnRH neurons can be addressed in their native environment. In the course of our own studies on fluorescent GnRH neurons in transgenic mice, we found that this phenotype could, in fact, be recognized on a topographical and

\footnotetext{
Received Sept. 11, 2000; revised Nov. 7, 2000; accepted Nov. 21, 2000.
}

This work was supported by the UK Biotechnology and Biological Sciences Research Council. We thank Sandra Dye for assistance with the mice.

Correspondence should be addressed to Allan E. Herbison, Laboratory of Neuroendocrinology, The Babraham Institute, Cambridge CB2 4AT, UK. E-mail: allan.herbison@bbsrc.ac.uk.

Copyright (C) 2021 Society for Neuroscience 0270-6474/21/11067-09 $\$ 15.00 / 0$ morphological basis in a relatively reliable manner. Thus, by combining visual identification with post hoc single-cell RT-PCR characterization, we were able to demonstrate that approximately one-half of neurons selected on the basis of their location and morphology contained GnRH transcripts and therefore were GnRH neurons (Skynner et al., 1999b). Although somewhat more laborious, this approach does have the great benefit of avoiding any potential confounding effects of fluorescence and/or transgene expression in GnRH neurons.

In the present study, our goal was to provide a characterization of the basic membrane properties of native, unmodified GnRH neurons in the female mouse. The GnRH neurons transcend from what is believed to be a relatively quiescent state to one of episodic cyclical activity at puberty (Ojeda and Urbanski, 1994). Thus, we also compared the electrophysiological characteristics of juvenile and adult GnRH neurons to try and elucidate any fundamental electrophysiological differences that might underlie their functional maturation. On the basis of the responses of GnRH neurons to hyperpolarizing and depolarizing current injection, we have found that this neuronal phenotype does not exhibit a single electrophysiological profile but that, surprisingly, up to four different types can be identified. Furthermore, we provide evidence that the prevalence of the various cell types changes across the time of puberty, as may the levels of functional calcium channels. Such observations indicate that multiple levels of functional heterogeneity exist in a development-dependent manner within the GnRH phenotype of the mouse.

\section{MATERIALS AND METHODS}

Preparation of brain slices incorporating GnRH neurons. All female mice (CBA/CaxC57BL/6J) were bred and housed (lights on at 7:00 A.M. and off at 7:00 P.M.) at The Babraham Institute and treated in accordance 
with UK Home Office regulations under project 80/1005. Vaginal smears were taken on a daily basis to identify adult female mice at diestrous or estrous stages of the ovarian cycle. Between 9:00 and 11:00 A.M., juvenile (postnatal day 15-22) and adult (day 50-70) female mice were anesthetized with isoflurane-RM (Rhone Merieux, Harlow, UK) and decapitated, and their brains were rapidly removed and placed in ice-cold bicarbonate-buffered artificial CSF (ACSF) of the following composition (in mM): $118 \mathrm{NaCl}, 3 \mathrm{KCl}, 0.5 \mathrm{CaCl}_{2}, 6.0 \mathrm{MgCl}_{2}, 11 \mathrm{D}$-glucose, 10 HEPES, and $25 \mathrm{NaHCO}_{3}$ (pH 7.4 when bubbled with $95 \% \mathrm{O}_{2}$ and $5 \%$ $\mathrm{CO}_{2}$ ). Brains were blocked and glued with cyanoacrylate to the chilled stage of an Oxford Vibratome (General Scientific, Redhill, UK), and $150-\mu \mathrm{m}$-thick coronal slices containing the medial septum through to the preoptic area were prepared. The slices were then incubated at $30^{\circ} \mathrm{C}$ for $30 \mathrm{~min}$ in oxygenated recording ACSF (rACSF) consisting of (in mM): $118 \mathrm{NaCl}, 3 \mathrm{KCl}, 2.5 \mathrm{CaCl}_{2}, 1.2 \mathrm{MgCl}_{2}, 11 \mathrm{D}$-glucose, $10 \mathrm{HEPES}$, and 25 $\mathrm{NaHCO}_{3}, \mathrm{pH} 7.3$, and thereafter kept at room temperature $\left(20-23^{\circ} \mathrm{C}\right)$ for at least $1 \mathrm{hr}$ before recording.

Whole-cell recording of GnRH neurons. Slices were transferred to the recording chamber, held submerged, and continuously superfused with $\mathrm{rACSF}$ at a rate of $6 \mathrm{ml} / \mathrm{min}$. The slices were viewed with an upright Axioskop FS microscope (Carl Zeiss, Jena, Germany) with a $40 \times$ immersion objective (Achroplan $0.75 \mathrm{~W}, \mathrm{Ph} 2$, Zeiss), giving a total magnification of $640 \times$ and Normaski differential interference contrast optics. To aid visualization of neurons, a CCD camera (Sony Corporation, Tokyo, Japan) was mounted on the microscope and connected to a monochrome monitor (Panasonic). All recordings were made at room temperature $\left(20-23^{\circ} \mathrm{C}\right)$. Patch pipettes were pulled from thin-walled borosilicate glass capillary tubing $(1.5 \mathrm{~mm}$ outer diameter, Clark Electromedical, Reading, UK) on a Flaming/Brown puller (P-97; Sutter Instruments Co., Novato, CA). Pipette tips were coated with either Sylgard resin (Dow Corning 184) or a wax pen (Dako, Glostrup, Denmark) and fire-polished to a final resistance of 6-12 $\mathrm{M} \Omega$. The pipette solution was passed through a disposable $0.22 \mu \mathrm{m}$ filter before use and contained (in mM): $140 \mathrm{KCl}, 1 \mathrm{CaCl}_{2}, 1 \mathrm{MgCl}_{2}, 10 \mathrm{HEPES}, 4 \mathrm{MgATP}$, $0.1 \mathrm{Na}_{2}$ GTP, 10 EGTA, with pH adjusted to 7.3 with KOH. The reference electrode was a glass bridge containing $4 \%$ agar-saline, of which one end was placed in the recording chamber and the other end in a $3 \mathrm{M}$ $\mathrm{KCl}$-containing side chamber connected to ground, via an $\mathrm{Ag} / \mathrm{AgCl}$ pellet.

Whole-cell recordings were performed as described previously (Hamill et al., 1981) using an Axoclamp-2B amplifier (Axon Instruments, Foster City, CA) operating in bridge mode. Bridge balance was checked frequently because of changes in series resistance. Current and voltage were simultaneously generated and sampled on-line using a Digidata 1200 (Axon Instruments) interface connected to an IBM PC/AT clone. Signals were filtered $(0.3-10 \mathrm{kHz}$, Bessel filter of Axoclamp-2B) before digitizing at a rate of $5 \mathrm{kHz}$. Acquisition and subsequent analysis of the acquired data were performed using the "pClamp6" suite of software (Axon Instruments). In addition, current and voltage signals were recorded simultaneously onto a chart recorder (Gould TA 240, Valley View, OH) and DAT recorder (DTR 1204, Biological Sciences, Claix, France). Traces and voltage-current curves were plotted using "Origin 5 " computer software (MicroCal Software, Northampton, MA).

After recordings of up to $1 \mathrm{hr}$ duration, the cytoplasmic contents of the recorded neuron were harvested under visual control, and single-cell RT-PCR was used to examine for the presence of GnRH transcripts as reported previously (Skynner et al., 1999b). Five juvenile GnRH neurons exhibiting a silent-type electrophysiological profile were also assessed for the presence of GFAP transcripts, again exactly as detailed previously (Skynner et al., 1999b). As controls, the contents of cells located outside the distribution of the GnRH neurons were harvested and processed for GnRH RT-PCR, as were the contents of electrodes placed in the slice but not used to harvest cellular contents (mock harvests).

Determination of membrane properties. Input resistance and membrane time constants of neurons were estimated from small $(0.02-0.1 \mathrm{nA}, 100$ msec duration) hyperpolarizing steps from resting membrane potential. Passing brief (20-30 msec) duration current pulses through the recording electrode generated single action potentials. Parameters such as spike amplitude, spike threshold, spike overshoot, and duration were measured and given as mean \pm SEM. Spike duration was measured as two-thirds of the amplitude from baseline to peak. Afterhyperpolarizing potentials were characterized as those found to occur immediately after depolarization. Statistical analysis was undertaken by ANOVA with post hoc two-tailed $t$ tests.

All drugs and reagents were applied via the superfusing ACSF solu-
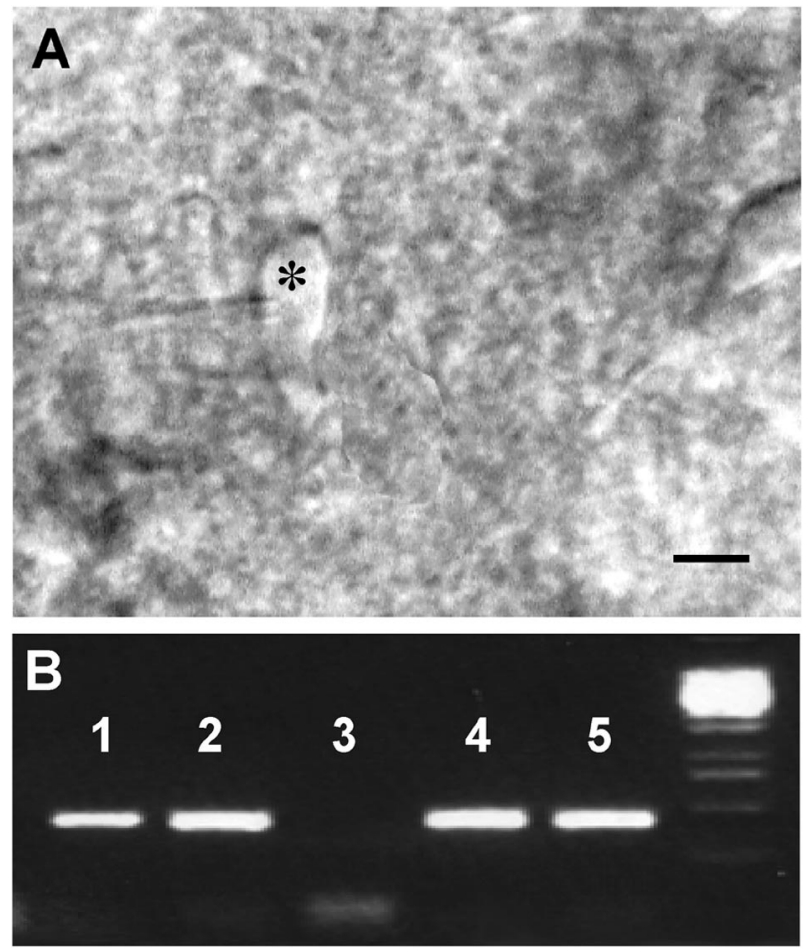

Figure 1. A, High-power photomicrograph of a patched bipolar-type neuron (asterisk) located in the rostral preoptic area subsequently proven to express GnRH transcripts. B, Gel showing the presence of $213 \mathrm{bp}$ GnRH amplicons in cells 1,2, 4, and 5. DNA $1 \mathrm{~kb}$ ladder is to the right.

tion. Solutions were switched manually by means of a six-way tap, ensuring that the bath was completely exchanged with control solution between drug application $(\sim 20 \mathrm{sec})$. Unless stated otherwise, all reagents were purchased from $\mathrm{BDH} / \mathrm{Sigma}$ (Poole, UK). The drugs used were 4-aminopyridine (4-AP; Sigma), barium chloride $\left(\mathrm{BaCl}_{2}\right.$; Sigma), bicuculline methobromide (Tocris, Bristol, UK), cadmium chloride $\left(\mathrm{CdCl}_{2}\right.$; Sigma), tetraethylammonium chloride (TEA-Cl; Lancaster Synthesis), and tetrodotoxin (Alexis Corporation, San Diego, CA).

\section{RESULTS}

\section{Identification of GnRH neurons}

Using thin slices of the forebrain, neurons of $\sim 10 \mu \mathrm{m}$ diameter that exhibited a bipolar-type morphology with a vertical orientation were identified within the medial septum and rostral preoptic area (Fig. $1 A$ ). Post-recording characterization with single-cell RT-PCR (Fig. $1 B$ ) revealed the presence of GnRH amplicons in $82 \%(31 / 38)$ of morphologically identified neurons in juvenile animals compared with $63 \%$ (44/69) of similarly identified cells in the adult mouse. The visualization of putative $\mathrm{GnRH}$ neurons was greatly facilitated by the lack of extensive fiber tracts in the brain of juvenile mice. No GnRH transcripts were detected in the cell contents of neurons harvested from outside the medial septum and rostral preoptic area, or in "mock harvests." The 213 bp amplicon product (Fig. 1B) resulting from RT-PCR has been shown previously to represent authentic murine GnRH-I cDNA (Skynner et al., 1999b). Although providing positive amplicons with hypothalamic cDNA, the GFAP primers failed to detect any GFAP transcripts in the five silent-type GnRH neurons recorded in juvenile mice. In our hands, the post-recording identification was found to be dependent on the length of our recording; long (>75 min) recordings invariably resulted in no transcripts being detected. We therefore established a recording window of $\leq 1 \mathrm{hr}$ 
Table 1. Summary of intrinsic properties of GnRH neurons recorded in juvenile and adult female mice

\begin{tabular}{|c|c|c|c|c|}
\hline & \multirow[b]{2}{*}{$\begin{array}{l}\text { Juvenile mice } \\
(n=31)\end{array}$} & \multicolumn{3}{|l|}{ Adult female mice } \\
\hline & & $\begin{array}{l}\text { All adult mice } \\
(n=44)\end{array}$ & $\begin{array}{l}\text { Estrous mice } \\
(n=17)\end{array}$ & $\begin{array}{l}\text { Diestrous mice } \\
(n=27)\end{array}$ \\
\hline Resting membrane potential (mV) & $\begin{array}{l}-65.4 \pm 1.5 \\
(-47 \text { to }-85)\end{array}$ & $\begin{array}{l}-69.2 \pm 1.1 \\
(-52 \text { to }-85)\end{array}$ & $-68.6 \pm 2.1$ & $-69.1 \pm 1.2$ \\
\hline Input resistance $(\mathrm{G} \Omega$ ) & $\begin{array}{c}1.1 \pm 0.2 \\
(0.03-2.8)\end{array}$ & $\begin{array}{c}1.5 \pm 0.1 \\
(0.36-3.18)\end{array}$ & $1.6 \pm 0.2$ & $1.4 \pm 0.1$ \\
\hline Membrane time constant (msec) & $\begin{array}{l}39.0 \pm 4.4 \\
(3.0-91.1)\end{array}$ & $\begin{array}{l}44.8 \pm 3.5 \\
(12.1-110.3)\end{array}$ & $45.5 \pm 4.1$ & $43.5 \pm 5.0$ \\
\hline Threshold potential of spike (mV) & $\begin{array}{l}-39.7 \pm 1.7 \\
(-25.5 \text { to }-50.3)\end{array}$ & $\begin{array}{l}-33.9 \pm 2.9 \\
(-27.7 \text { to }-51.8)\end{array}$ & $-36.0 \pm 0.7$ & $-38.5 \pm 1.6$ \\
\hline Amplitude of spike (mV) & $\begin{array}{l}83.1 \pm 2.8 \\
(54.0-101.3)\end{array}$ & $\begin{array}{l}84.2 \pm 1.8 \\
(67.4-121.3)\end{array}$ & $85.2 \pm 3.2$ & $83.6 \pm 2.1$ \\
\hline Overshoot of spike (mV) & $\begin{array}{c}18.5 \pm 2.0 \\
(-2.1 \text { to } 33.9)\end{array}$ & $\begin{array}{c}15.4 \pm 2.2 \\
(-4.5 \text { to } 49.5)\end{array}$ & $18.3 \pm 4.2$ & $13.5 \pm 2.4$ \\
\hline Duration of spike (msec) & $\begin{array}{l}1.8 \pm 0.1 \\
(1.2-2.8)\end{array}$ & $\begin{array}{l}2.0 \pm 0.1 \\
(0.8-3.4)\end{array}$ & $1.6 \pm 0.1$ & $2.3 \pm 0.1^{*}$ \\
\hline
\end{tabular}

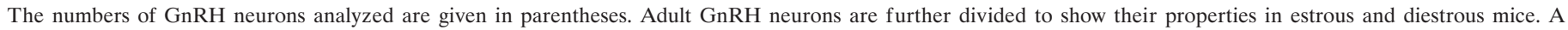

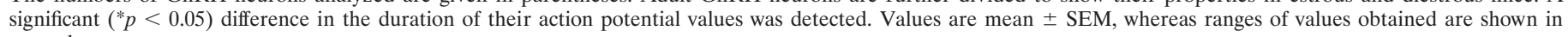
parentheses.

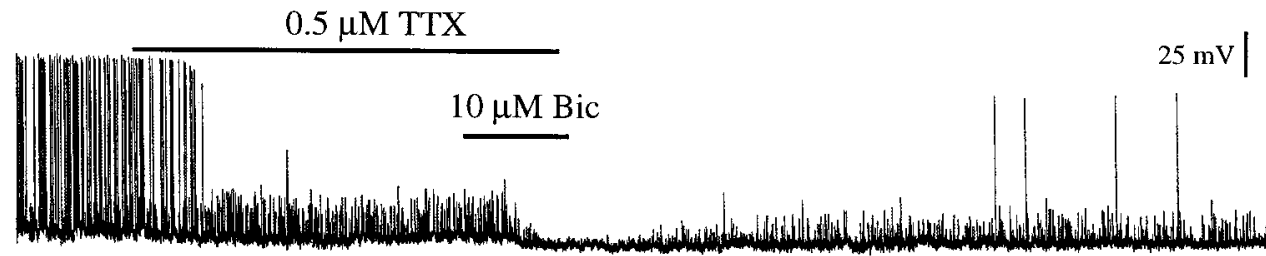

a) control

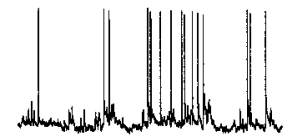

b) $0.5 \mu \mathrm{M} \mathrm{TTX}$

c) $10 \mu \mathrm{MBic}+\mathrm{TTX}$

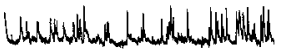

$1 \mathrm{~min}$

d) washout

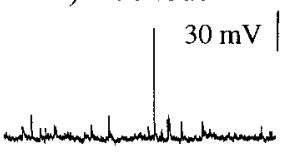

$5 \mathrm{~s}-$
Figure 2. Spontaneous synaptic activity recorded in GnRH neurons from a 55-d-old female mouse. Top trace shows a continuous trace of an experiment in which TTX $(0.5 \mu \mathrm{M})$ and bicuculline (10 $\mu \mathrm{M})$ were applied to a GnRH neuron at its resting membrane potential of -70 $\mathrm{mV}$. The bottom traces are expanded 1 sec traces recorded in control $(a)$, the presence of TTX $(b)$, the presence of both bicuculline and TTX $(c)$, and after washout $(d)$. to ensure the detection of GnRH transcripts in recorded GnRH neurons.

\section{General membrane properties and spontaneous activities of GnRH neurons}

Using the whole-cell configuration, the resting and active membrane properties of juvenile and adult GnRH neurons were examined in bridge mode. Resting membrane potentials were determined immediately after the rupture of the cell membrane and juvenile GnRH neurons found to have a mean resting potential of $-65.4 \pm 1.5 \mathrm{mV}(n=31)$. Adult GnRH neurons displayed resting membrane potentials of a comparable range, with a mean value of $-69.2 \pm 1.1 \mathrm{mV}(n=44)$ (Table 1$)$. We also found that the input resistance, membrane time constant, spike threshold, and action potential characteristics of juvenile and adult GnRH neurons were not significantly different (Table 1 ).

In total, 27 of the adult GnRH neurons were from diestrous mice, and 17 were from estrous animals. With the single exception of action potential duration, which was significantly greater in diestrous mice $(p<0.05)$, no differences were detected in the intrinsic membrane properties of adult GnRH neurons at these stages of the estrous cycle (Table 1).
Approximately $80 \%$ of adult $(34 / 44 ; 77 \%)$ and $60 \%$ of juvenile $(18 / 31 ; 58 \%)$ GnRH neurons were found to be spontaneously active under symmetrical chloride ion recording conditions (Fig. 2), with firing rates ranging from 0.02 to $6.5 \mathrm{~Hz}$ (adult, $0.9 \pm 0.4$ $\mathrm{Hz}$; juvenile, $0.4 \pm 0.1 \mathrm{~Hz})$. The addition of TTX $(0.5 \mu \mathrm{M})$ to the bathing medium revealed that the great majority of this activity was action potential independent and thus spontaneous in nature (Fig. 2). Further addition of bicuculline (10 $\mu \mathrm{M})$ almost completely abolished these spontaneous events (Fig. 2) in both adult $(n=6)$ and juvenile $(n=5)$ GnRH neurons. Indeed, bath application of bicuculline alone (without preapplication of TTX) was able to abolish almost all spontaneous events (data not shown). The effects of TTX and bicuculline were reversible on washout (Fig. 2), whereas complete recovery from compounds was dependent on the period of their exposure to the slices.

\section{Electrophysiological characteristics of adult GnRH neurons}

The families of electrotonic potentials evoked in individual adult GnRH neurons in response to short (20-30 msec duration) and long $(200 \mathrm{msec})$ duration intracellular current pulses were found 


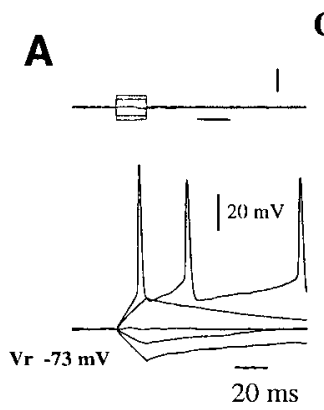

Cell type I
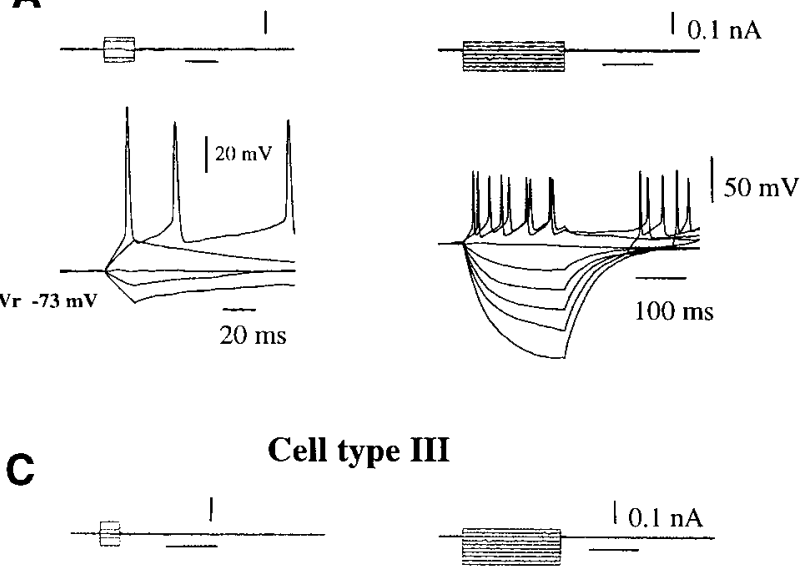

Cell type III
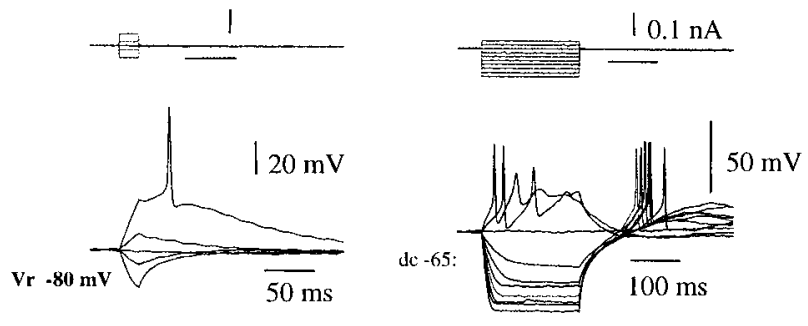

B
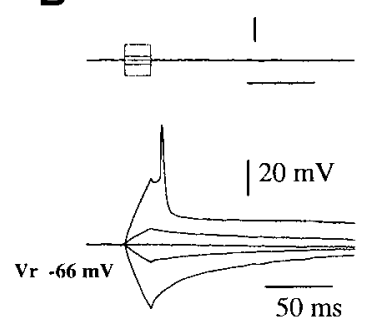

\section{Cell type IV}

D
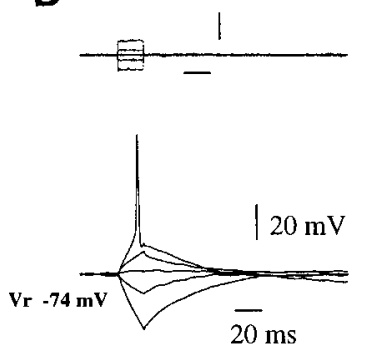

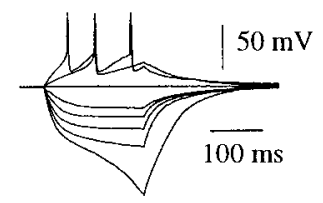

Cell type II
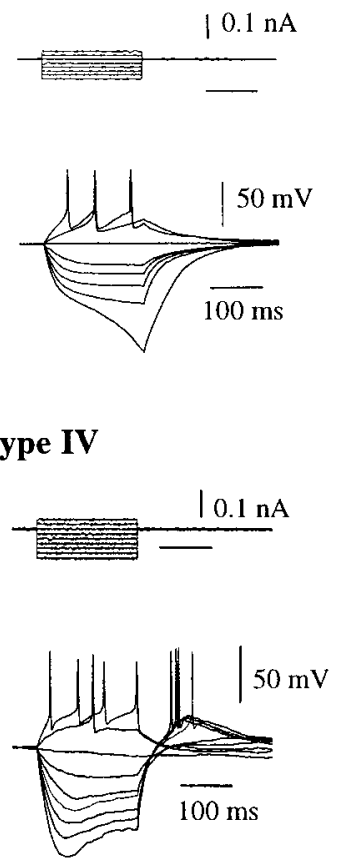

Figure 3. Intrinsic membrane properties of four types (I-IV) of GnRH neurons recorded in adult female mice. $A-D$, Responses to 20 and 200 msec depolarizing and hyperpolarizing current pulses. In all four cell types, threshold stimulation elicited a single action potential, which clearly shows depolarizing afterpotential (ADP) of various duration and amplitude. In each cell type, $200 \mathrm{msec}$ duration hyperpolarizing current injection revealed the presence of inward rectifiers with distinct kinetics. The four cell types are characterized on the basis of their inward rectification as well as the absence of rebound depolarization in type II cells and the inability to fire repetitively after depolarization in type III cells. Resting membrane potentials are given for each cell.

Table 2. Comparison of intrinsic properties of the different GnRH neuronal cell types in juvenile and adult female mice

\begin{tabular}{|c|c|c|c|c|c|c|c|}
\hline & \multicolumn{4}{|l|}{ Adult female } & \multicolumn{3}{|l|}{ Juvenile mice } \\
\hline & $\begin{array}{l}\text { Type I } \\
(\mathrm{D}=10) \\
(\mathrm{E}=11)\end{array}$ & $\begin{array}{l}\text { Type II } \\
(\mathrm{D}=12) \\
(\mathrm{E}=4)\end{array}$ & $\begin{array}{l}\text { Type III } \\
(\mathrm{D}=3) \\
(\mathrm{E}=2)\end{array}$ & $\begin{array}{l}\text { Type IV } \\
(\mathrm{D}=2) \\
(\mathrm{E}=0)\end{array}$ & $\begin{array}{l}\text { Type I } \\
(n=19)\end{array}$ & $\begin{array}{l}\text { Type II } \\
(n=2)\end{array}$ & $\begin{array}{l}\text { Silent } \\
(n=10)\end{array}$ \\
\hline Resting membrane potential (mV) & $-69.0 \pm 1.6$ & $-68.3 \pm 1.7$ & $-73.1 \pm 3.5$ & -63.6 & $-65.4 \pm 1.5$ & -61.9 & $-67.6 \pm 3.4$ \\
\hline Input resistance $(\mathrm{G} \Omega)$ & $1.6 \pm 0.2$ & $1.3 \pm 0.2$ & $1.2 \pm 0.1$ & 1.2 & $1.1 \pm 0.2$ & 1.5 & $0.6 \pm 0.4$ \\
\hline Time constant $(\tau)(\mathrm{msec})$ & $52.1 \pm 5.2$ & $38.3 \pm 4.8$ & $29.7 \pm 6.6$ & 35.8 & $39.0 \pm 4.4$ & 57.0 & $30.8 \pm 9.7$ \\
\hline Action potential threshold $(\mathrm{mV})$ & $-33.0 \pm 4.4$ & $-38.7 \pm 2.0$ & $-31.7 \pm 2.7$ & -44.0 & $-39.7 \pm 1.7$ & -34.3 & \\
\hline $\begin{array}{l}\text { Amplitude of action potential } \\
(\mathrm{mV})\end{array}$ & $83.2 \pm 2.6$ & $84.8 \pm 3.0$ & $90.0 \pm 5.0$ & 78.5 & $83.1 \pm 2.8$ & 85.2 & \\
\hline $\begin{array}{l}\text { Overshoot of action potential } \\
(\mathrm{mV})\end{array}$ & $13.7 \pm 3.2$ & $16.0 \pm 3.9$ & $20.3 \pm 7.0$ & 15.1 & $18.5 \pm 2.0$ & 22.9 & \\
\hline $\begin{array}{l}\text { Duration of action potential } \\
\quad(\mathrm{msec})\end{array}$ & $1.9 \pm 0.2$ & $2.2 \pm 0.2$ & $1.9 \pm 0.2$ & 1.2 & $1.8 \pm 0.1$ & 2.1 & \\
\hline Spontaneously active & $76 \%$ & $75 \%$ & $100 \%$ & $50 \%$ & $89 \%$ & $50 \%$ & \\
\hline Percentage with ADP & $43 \%$ & $25 \%$ & $60 \%$ & $0 \%$ & $32 \%$ & $50 \%$ & \\
\hline Percentage with AHP & $5 \%$ & $6 \%$ & $0 \%$ & $50 \%$ & $37 \%$ & $50 \%$ & \\
\hline
\end{tabular}

Numbers (mean \pm SEM) of neurons are given in parentheses. D, Diestrous; E, estrous.

to be heterogeneous (Fig. 3). The most striking difference was observed in response to $200 \mathrm{msec}$ hyperpolarizing current pulses where four main profiles (types I-IV) were consistently observed (Fig. 3; Table 2). The most abundant GnRH neurons (type I, $48 \%$ ) exhibited a linear-type voltage relationship in response to hyperpolarizing current pulses (Fig. $3 A$ ), whereas in type II cells $(36 \%)$ this linear relationship was not maintained with larger hyperpolarization and resulted in "runaway" of the voltage transient and the generation of negative-going spike (Fig. $3 B$ ). In the other two populations of adult GnRH neurons, negative current pulses evoked inward rectifying conductances with properties of either the anomolous rectifier (type III, 11\%) (Fig. $3 C$ ) or $I_{\mathrm{Q} / \mathrm{H}}$ (type IV, 5\%) (Fig. 3D), with mixed permeability for sodium and potassium rectification (Halliwell and Adams, 1982; Rudy, 1988; Pape, 1996). Rebound depolarization was observed after the termination of the hyperpolarizing steps in all cell types, except for type II (Fig. 3B), where it was never detected. The final distinguishing feature of the four cell types was observed in their 
A

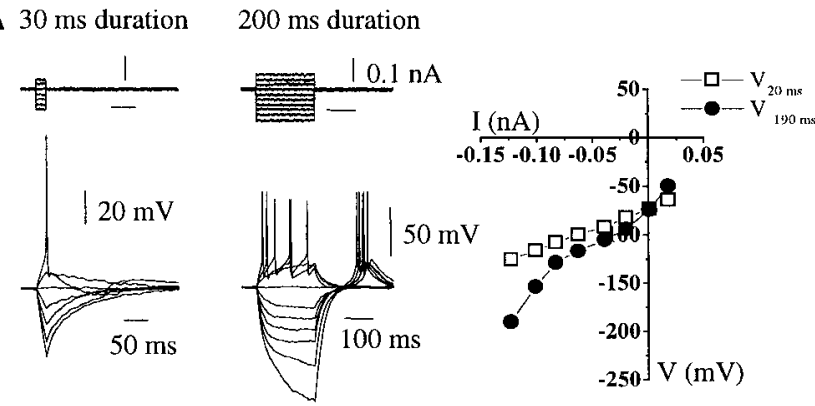

B

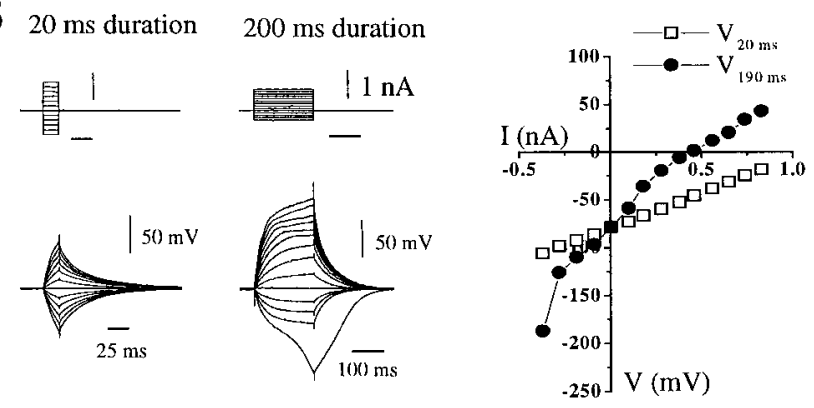

Figure 4. Intrinsic membrane properties of $\mathrm{GnRH}$ neurons recorded in juvenile female mice. $A$, Type I neuron in which action potentials could be evoked with 20 and $200 \mathrm{msec}$ depolarizing and hyperpolarizing current pulses. Voltage-current relationship plotted from the end of $200 \mathrm{msec}$ duration pulses. Note the presence of afterhyperpolarization with the 20 msec depolarizing pulse. $B$, Silent-type neuron in which no action potential could be evoked with either 20 or $200 \mathrm{msec}$ depolarizing and hyperpolarizing current pulses. Voltage-current relationship plotted from the end of $200 \mathrm{msec}$ pulse. The resting membrane potential was $-67 \mathrm{mV}$ in cell $A$ and $-72 \mathrm{mV}$ in cell $B$.

response to $200 \mathrm{msec}$ depolarizing current pulses where trains of fast action potentials, varying in their frequency of firing, were observed in cell types I, II, and IV, whereas cell type III displayed an initial fast action potential followed by trains of smaller and slower spikes (Fig. 3C).

The short duration stimulation evoked single action potentials that displayed afterspike depolarizing potentials (ADPs) of varying amplitude and duration as well as AHPs (Fig. 3). Delayed AHPs were not observed in any GnRH neurons. Although AHPs became more noticeable when cells were held at depolarized potentials of $-55 \mathrm{mV}$ (data not shown), the presence of ADPs and AHPs were found only in subpopulations of all four cell types at their resting membrane potential (Table 2). The resting membrane potential, input resistance, membrane time constant, and action potential threshold and characteristics were not different among any of the cell types (Table 2). Of the $17 \mathrm{GnRH}$ neurons recorded from estrous mice, $65,23,12$, and $0 \%$ were judged to be of types I, II, III, and IV, respectively, compared with the 37, 44, 11 , and $8 \%$ categorization of GnRH neurons from diestrous mice $(n=27)$.

\section{Electrophysiological characteristics of juvenile female mice}

Recordings from the 31 juvenile GnRH neurons revealed that the majority ( $n=19 ; 61 \%)$ exhibited firing properties similar to those of type I GnRH neurons in adult animals with a linear-type voltage response to hyperpolarizing current and rebound depolarization combined with sustained trains of fast action potentials to depolarizing current (Fig. 4A). A small population of neurons $(n=2 ; 6 \%)$ displayed type II-like characteristics (data not shown). In terms of their intrinsic membrane properties, these juvenile GnRH neurons were not found to be different from the equivalent adult GnRH cell types (Table 2). Surprisingly, however, the rest of the juvenile GnRH neurons $(n=10 ; 32 \%)$ failed to fire action potentials, regardless of the amplitude of depolarizing current pulses (up to $0.5 \mathrm{nA}$ ), and were thus termed silent cells (Fig. 4B). These silent cell types displayed a range of rectification in response to hyperpolarizing current pulses as seen in types I-III (e.g., type II in Fig. 4B). Indeed, their intrinsic properties differed from firing cells only in their mean input resistance, which was very much lower at $0.60 \pm 0.4 \mathrm{G} \Omega(p<$ 0.05 ) (Table 2). Current-voltage relationship plots of these neurons revealed strong outward and inward rectification (Fig. 4B).

Although the percentage of juvenile GnRH neurons (33\%) that displayed ADPs was similar to that of adults (36\%), many more juvenile GnRH neurons (38\%) were found to exhibit AHPs (Fig. $4 A$ ) compared with adult GnRH cells (7\%) (Table 2).

\section{Effects of ion channel blockers on the excitability of GnRH neurons}

$T T X$

Adult GnRH neurons were found to fire $\mathrm{Na}^{+}$-dependent action potentials, because $0.5 \mu \mathrm{M}$ TTX abolished evoked action potentials in all cells tested $(n=40)$ (Fig. 5A). In response to incremental increases in depolarizing current pulses in the presence of TTX, a strong outward rectification was observed with the concomitant unmasking of a hyperpolarization "notch" at the beginning of the voltage trace (Fig. $5 A$ ). This likely represents the presence of the A-type potassium conductance $\left(I_{\mathrm{A}}\right)$ (Rudy, 1988). The corresponding current-voltage relationship measured at the end of the 200 msec current pulses showed that TTX had no effect on conductances evoked in the hyperpolarizing direction but had a marked rectification in the depolarizing direction, as revealed by the flat region positive to $-50 \mathrm{mV}$ (Fig. $5 A$ ). The rebound depolarization spikes after large hyperpolarizing current pulses were also abolished, or occasionally attenuated, by TTX (Fig. $5 A)$.

The application of TTX to juvenile GnRH neurons also abolished fast action potentials and revealed the presence of a strong outward rectification (Fig. $5 B$ ). Interestingly, this hyperpolarization notch could often be seen in juvenile GnRH neurons even without TTX $(n=15)$ (Fig. $5 B)$. In many juvenile GnRH neurons (47\%), the application of TTX also revealed the presence of repetitive $\mathrm{Ca}^{2+}$ spikes (Fig. $5 B a$ ), which subsequently resulted in an increase in the amplitude of the AHP conductance (Fig. 5Bb). Similar TTX-independent spikes were only observed in $15 \%$ of adult GnRH neurons (data not shown).

\section{Tetraethylammonium}

In several experiments, the effects of outward current blockers on GnRH neurons were examined (Fig. 6). In both juvenile $(n=2)$ and adult $(n=3) \mathrm{GnRH}$ neurons, $1 \mathrm{~mm}$ TEA was found to prolong the duration of the action potential and decrease cell excitability (Fig. 6A). No effect of TEA was observed on the resting membrane potential or on the amplitude of responses evoked with negative current pulses. However, in two silent-type GnRH neurons, TEA depolarized the membrane potential by 2 $\mathrm{mV}$ and also increased the amplitude of electrotonic potentials evoked with depolarizing current pulses. However, TEA had no effect in the hyperpolarizing direction on these cells (data not shown). Although TEA blocks a wide range of potassium con- 

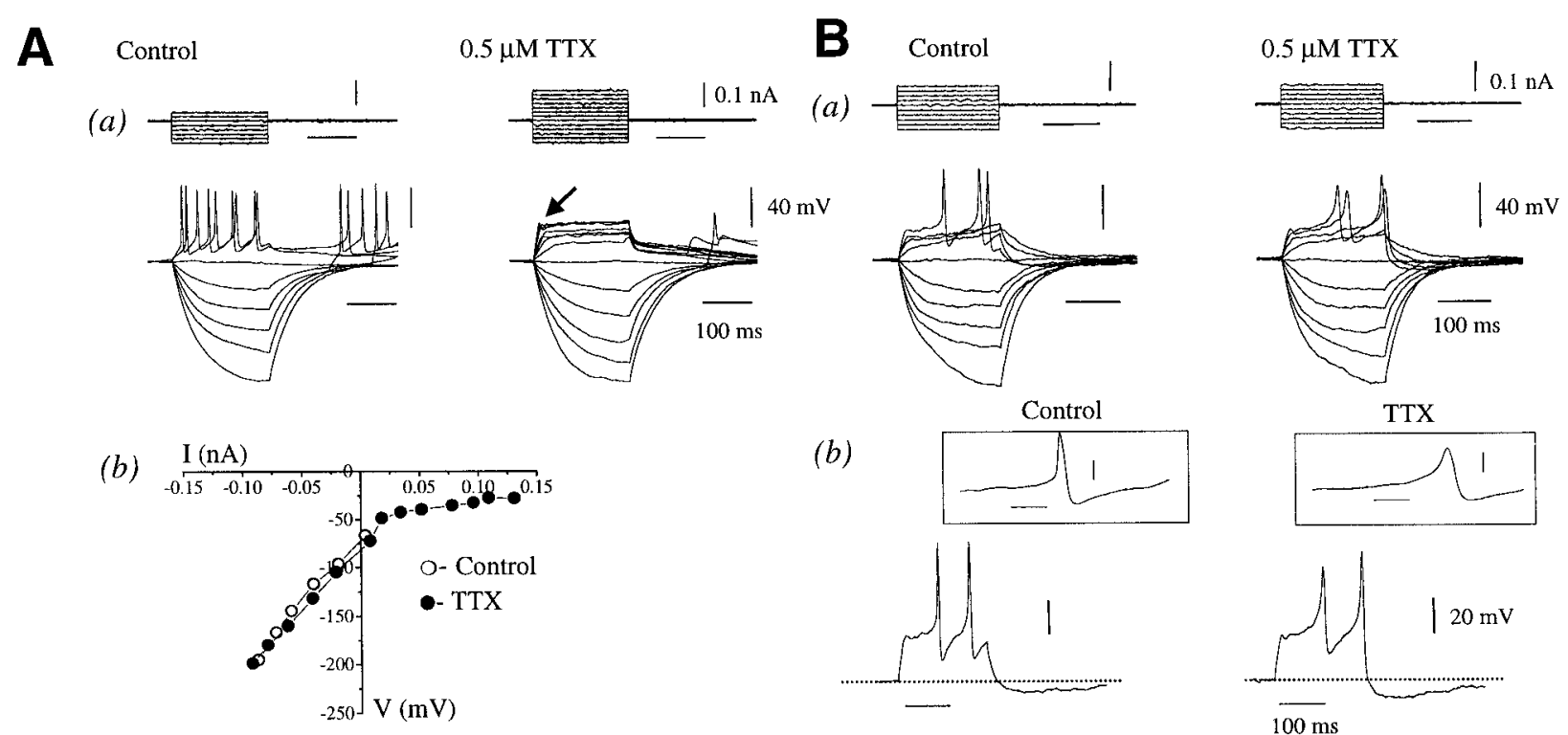

(b)
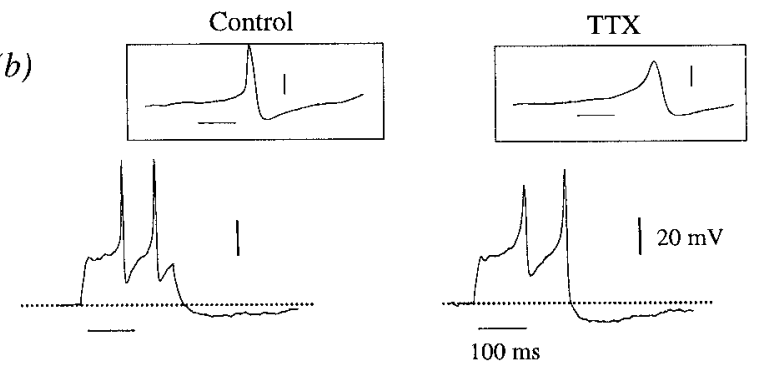

Figure 5. The effect of tetrodotoxin (TTX) on cell type I in adult and juvenile GnRH neurons. Families of voltage were evoked in adult GnRH ( $A a)$ and in juvenile GnRH neurons $(B a)$ with 200 msec current pulses in control and in the presence of TTX. The corresponding voltage-current relationship obtained from the adult GnRH neuron $(A b)$ shows marked rectification with depolarizing pulses. Note the presence of an "A" notch (arrow) in the presence of TTX. $B b$, Expanded traces in response to $0.06 \mathrm{nA}$ depolarizing current pulse, showing that in the presence of TTX, calcium spikes are revealed. The insets illustrate the differences in the shape and duration of sodium (no TTX) and calcium (in TTX) spikes. The resting membrane potential is $-74 \mathrm{mV}$ in cell $A$ and $-74 \mathrm{mV}$ in cell $B$.

ductances, the delaying of the repolarization phase in association with a decrease in cell excitability observed here would be most compatible with the blocking of a delayed rectifier $\left(I_{\mathrm{K}}\right)$ or large current (BK) calcium-activated potassium channel (Rudy, 1988).

\section{4-Aminopyridine}

The application of $100 \mu \mathrm{M} 4$-AP was found to increase adult GnRH neuron excitability $(n=2)$ (Fig. $6 B)$. This increase in excitability resulted from a decrease in spike latency and was observed as an increase in the frequency of spontaneous synaptic activities as well as evoked firing rates (Fig. 6B). This effect would be compatible with the blocking of an $I_{\mathrm{A}}$ conductance (Rudy, 1988). The addition of 4-AP $(100 \mu \mathrm{M})$ to two silent-type GnRH neurons was found to increase the amplitude of the electrotonic potentials evoked with depolarizing current pulses.

\section{Barium}

In four adult $\mathrm{GnRH}$ neurons, $\mathrm{Ba}^{2+}$ applied at $100 \mu \mathrm{M}$ was found to increase cell excitability but either had no effect on membrane potential $(n=3)$ or evoked a small $7 \mathrm{mV}$ increase $(n=1)$. The block produced by $\mathrm{Ba}^{2+}$ on the amplitude of electrotonic potentials evoked with hyperpolarizing currents was uniform but also observed in the depolarizing direction, blocking outward rectifiers (data not shown). Of all the potassium channel blockers examined, $\mathrm{Ba}^{2+}$ produced the most dramatic effects on the silenttype $\mathrm{GnRH}$ neurons found in juvenile animals; addition of $\mathrm{BaCl}_{2}$ $(100 \mu \mathrm{M})$ produced membrane depolarization (ranging from 21-44 $\mathrm{mV} ; n=3$ ) concomitant with increases in resistance in both depolarizing and hyperpolarizing directions (Fig. 7). The effects of $\mathrm{Ba}^{2+}$ were readily reversed on washout (Fig. 7).

\section{Cesium}

Addition of the potassium channel blocker $\mathrm{CsCl}$ at $100 \mu \mathrm{M}$ had little to no effect on the $I-V$ relationship in type I neurons $(n=2$; data not shown). However, cesium $\left(\mathrm{Cs}^{+}\right)$produced a variable increase in the amplitude of the electrotonic potentials evoked with hyperpolarizing current pulses in types II, III, and IV GnRH neurons $(n=5)$ (Fig. 8). Indeed, it is well documented that the different inward rectifiers differ in their sensitivity to $\mathrm{Cs}^{+}$, and in the case of type III GnRH neurons (Fig. $8 A$ ), where it had the most pronounced effect, it was both voltage and concentration dependent. The effect produced at $100 \mu \mathrm{M}$ concentration was effective only on more negative jumps but became more uniform at $300 \mu \mathrm{M}$ concentration (Fig. 7). $\mathrm{Cs}^{+}$had little effect on the excitability of GnRH neurons and was reversible on washout.

\section{DISCUSSION}

Most GnRH neurons in mammalian species exhibit a bipolar-type morphology with a distinct vertical orientation (Silverman et al., 1994). As before (Skynner et al., 1999b), we show that many of the neurons displaying these characteristics contain GnRH transcripts and therefore are GnRH neurons. The specificity of this procedure is further indicated by the absence of GnRH amplicons in both mock harvests and cells located outside the GnRH distribution. It is important to recognize, however, that $\mathrm{GnRH}$ neurons which do not display a clear bipolar morphology will not be sampled in our procedure. Thus, although our results should be representative of the majority of GnRH neurons, they may not necessarily reflect the entire population. Notwithstanding these caveats, the present procedure has provided the means for the first detailed electrophysiological analysis of native mammalian GnRH neurons while avoiding any potential confounding effects that may arise from the investigation of transgenically modified, fluorescent GnRH neurons.

\section{Heterogeneity within the adult GnRH neuronal population}

Immunocytochemical and in situ hybridization studies have reported heterogeneity in GnRH neuron morphology (Wray and Hoffman, 1986) as well as their expression of specific receptors, 

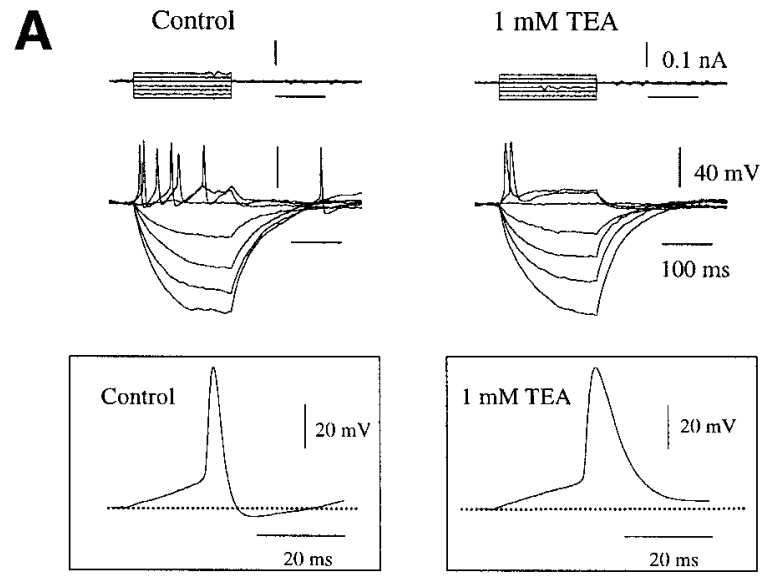

B
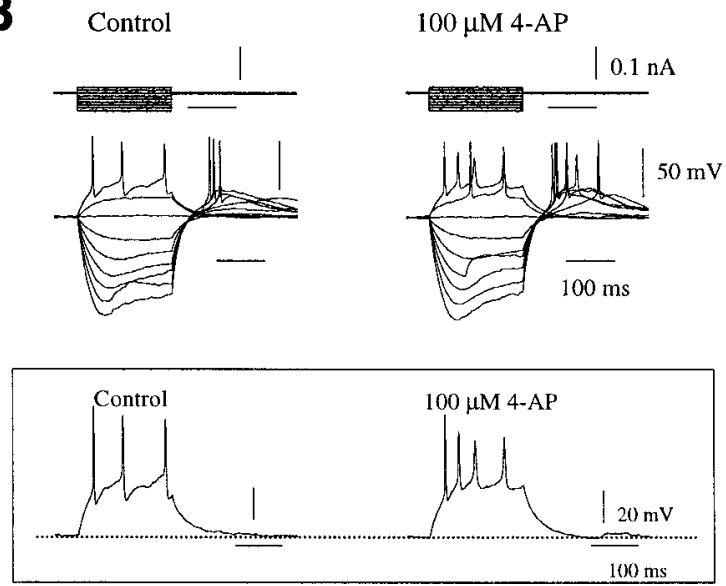

Figure 6. The effect of tetraethylammonium (TEA) and 4-aminopyridine $(4-A P)$ on the spike discharge of adult GnRH neurons. $A$, Families of voltage were evoked in cell type I, with $200 \mathrm{msec}$ hyperpolarizing and depolarizing current pulses in the presence and absence of $1 \mathrm{mM}$ TEA. TEA decreased cell excitability in GnRH neurons, and as shown by the inset, it produced this effect by broadening the action potential. $B$, Responses to $200 \mathrm{msec}$ depolarizing and hyperpolarizing current pulses in cell type IV in the presence of $100 \mu \mathrm{M} 4$-AP. 4-AP produced an increase in cell excitability by altering the repolarization phase of the action potential as shown in the inset. The resting membrane potential is -70 $\mathrm{mV}$ in cell $A$ and $-74 \mathrm{mV}$ in cell $B$.

immediate early genes, and neuropeptides, including GnRH itself (Hiatt et al., 1992; Merchenthaler et al., 1993; Porkka-Heiskanen et al., 1994; Wang et al., 1995; Gore et al., 1996; Simonian et al., 2000). We now provide direct evidence for functional heterogeneity in the basic membrane properties of these neurons. Most strikingly, the types III and IV GnRH neurons were found to display strong inward rectification to hyperpolarizing current pulses that were indicative of the presence of $I_{\mathrm{IR}}$ and $I_{\mathrm{Q} / \mathrm{H}}$, respectively. Experiments with $\mathrm{Cs}^{+}$provided further support for $I_{\mathrm{IR}}$-type potassium channels in type III GnRH neurons, as well as their less prominent existence in types II and IV cells. In contrast, type I GnRH neurons did not exhibit any inward rectification. Further distinguishing characteristics of the different cell types were the inability of type III GnRH neurons to fire repetitively in response to a depolarizing current and the absence of rebound depolarization in type II cells. This latter phenomenon suggests the likelihood of lower levels of functional T-type $\mathrm{Ca}^{2+}$ channels (Huguenard, 1996) in type II GnRH neurons compared with the others.

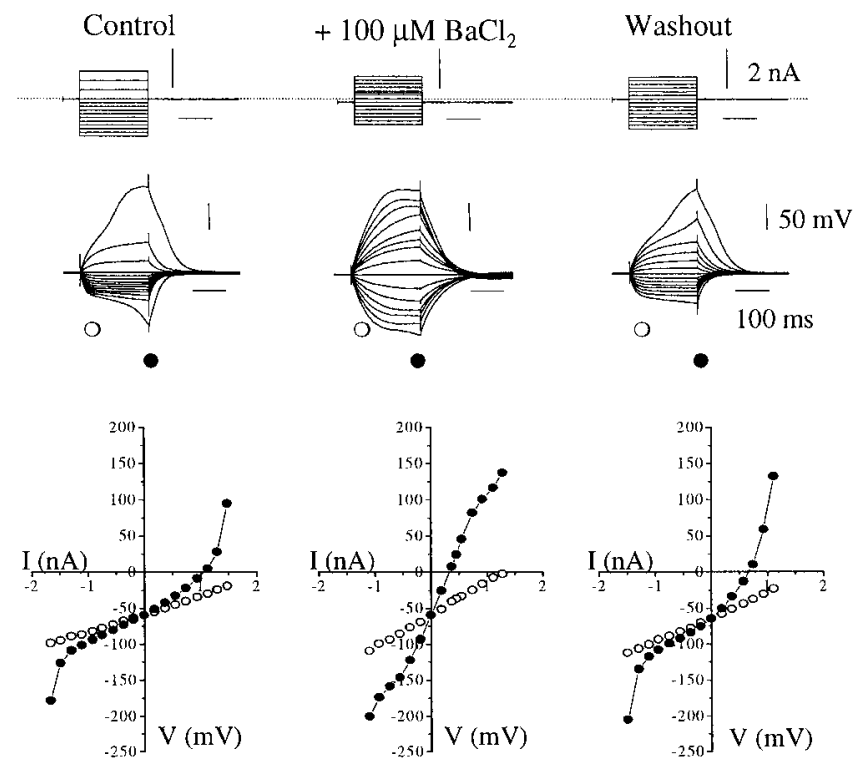

Figure 7. The effect of barium on GnRH neurons. Responses to 200 msec depolarizing and hyperpolarizing current pulses evoked in a silenttype juvenile GnRH neuron in control, on addition of $100 \mu \mathrm{M}$ barium and after washout. The corresponding voltage-current relationships at the beginning (30 msec, O) and end (190 msec, $)$ are plotted, revealing the presence of rectification with depolarizing and hyperpolarizing pulses. Note the blockade of both inward and outward rectification in $\mathrm{Ba}^{2+}$, which was readily reversible. Resting membrane potential was $-65 \mathrm{mV}$ but brought to $-70 \mathrm{mV}$ with $\mathrm{DC}$.
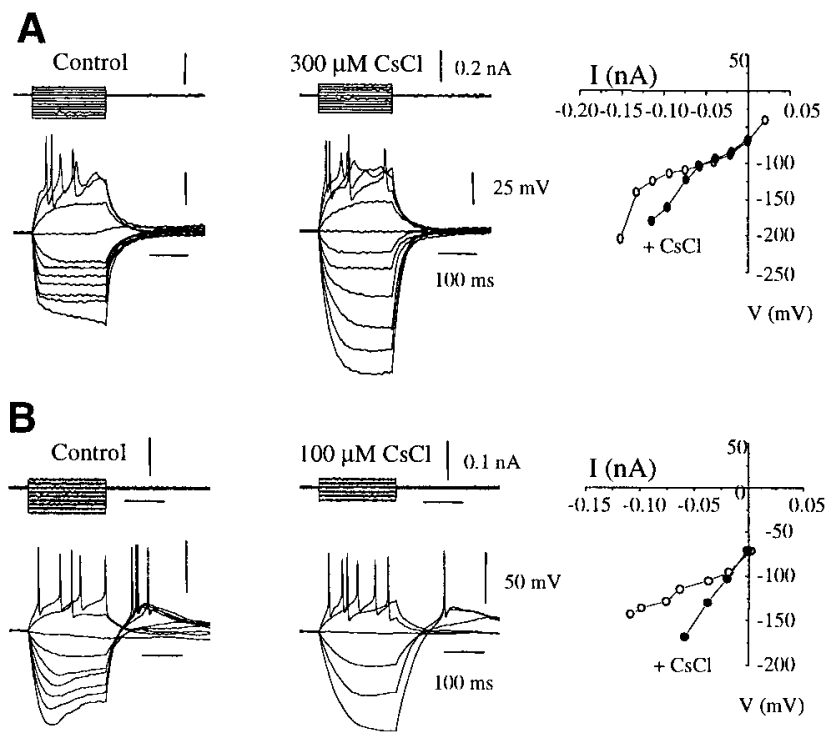

Figure 8. The effect of cesium on type III $(A)$ and type IV $(B)$ GnRH neurons. Families of voltage are evoked with $200 \mathrm{msec}$ depolarizing and hyperpolarizing current pulses in control and in the presence of 100 or $300 \mu \mathrm{M} \mathrm{Cs}^{+}$. Note the blockade of anomolous rectification $(A)$ and $I_{\mathrm{Q} / \mathrm{H}}$ $(B)$ by $\mathrm{Cs}^{+}$, without any effect on cell excitability. Voltage-current relationship plotted from the end of the $200 \mathrm{msec}$ pulse in control $(\bigcirc)$ and in the presence of cesium $(\bullet)$. Resting membrane potential was $-72 \mathrm{mV}$ in $A$ and $-75 \mathrm{mV}$ in $B$.

We were also able to demonstrate the presence of the $I_{\mathrm{A}}$ potassium conductance in GnRH neurons, although no particular relationship with the different cell types was found. In a similar manner, the ADP and AHP conductances were also found to exist in all four of the GnRH cell types but, interestingly, only in 
subpopulations of each. Calcium entry through $\mathrm{N}$-type $\mathrm{Ca}^{2+}$ channels has been proposed to underlie the AHP, whereas entry through $\mathrm{P} / \mathrm{Q}$ - and T-type $\mathrm{Ca}^{2+}$ channels is thought to be responsible for generation of ADP (Kobayashi et al., 1993; Sim and Allen, 1998). Together, these observations in native GnRH neurons indicate the existence of multiple layers of functional heterogeneity within the GnRH phenotype. At one level, there appears to be diversity in the levels of expression of different $\mathrm{Ca}^{2+}$ channels, although at another, this involves differential expression of channels underlying the $I_{\mathrm{IR}}$ and $I_{\mathrm{Q} / \mathrm{H}}$ conductances.

Previous electrophysiological studies have demonstrated the presence of $I_{\mathrm{K}}, I_{\mathrm{A}}$, and $I_{\mathrm{IR}}$, as well as low- and high-thresholdactivated calcium conductances, in immortalized GT1 cells (Bosma, 1993; Hales et al., 1994; Van Goor et al., 1999a,b) and cultured embryonic GnRH neurons of the mouse (Kusano et al., 1995). Although detailed information on the basic membrane properties of green fluorescent protein (GFP)-expressing GnRH neurons is not yet available, it is interesting to note that outward potassium currents indicative of $I_{\mathrm{A}}$ and $I_{\mathrm{K}}$ conductances were reported by Spergel and colleagues (1999). However, our observation of fast AHPs in only a minority of $\mathrm{GnRH}$ neurons is at odds with its presence in all GFP-GnRH cells (Spergel et al., 1999). The reasons underlying this difference are not clear, but it is worth noting that the GFP-GnRH neurons had much lower resting membrane potentials $(-55 \pm 4 \mathrm{mV})$, and this would likely enable greater calcium entry on depolarization and facilitate the AHP conductance. Also, the GFP-GnRH neurons analyzed were obtained from a range of 1 - to 24 -week-old male and female mice. It is important to note, however, that $\mathrm{GnRH}$ neurons in the ovariectomized guinea pig (Lagrange et al., 1995) also express $I_{\mathrm{A}^{-}}$ and $I_{\mathrm{IR}}$-type potassium currents and, interestingly, appear similar to the GnRH type IV neuron reported here.

The functional significance of different levels of multiple potassium and calcium ion channels in native $\mathrm{GnRH}$ neurons is not yet clear. However, the $I_{\mathrm{A}}, I_{\mathrm{K}}$, and AHP conductances have all been shown to play important roles in determining the repetitive firing patterns of neurons and are selectively modulated by neurotransmitter input (Rudy, 1988; Schwindt et al., 1988; Storm, 1990; Schoppa and Westbrook, 1999). The expression of these channels may well be critical in determining the specific patterned activities that control neurosecretory output from GnRH neurons. It is also of interest to note that a pacemaker role has been attributed to $I_{\mathrm{H}}$ (Kelly and Ronnekleiv, 1994; Pape, 1996), and its presence in a small population of GnRH neurons may be significant in the generation of synchronized release of GnRH. Furthermore, the presence of rebound depolarization in cell types I, II, and IV would result in any coordinated inhibitory input generating synchronized firing (Huguenard, 1996; Bean and McDonough, 1998) in the GnRH neurons of this type.

\section{Postnatal changes in GnRH neurons across puberty}

Because the profile of GnRH secretion is believed to change substantially after puberty (Ojeda and Urbanski, 1994), it was surprising to find relatively little difference between the basic membrane properties of juvenile and adult female GnRH neurons. Neurons recorded from both age groups were spontaneously active and this was shown to result almost exclusively from a substantial GABAergic barrage signaling through the $\mathrm{GABA}_{\mathrm{A}}$ receptor. This receptor has also been identified in mouse GFPGnRH and guinea pig GnRH neurons (Lagrange et al., 1995; Spergel et al., 1999). Much of this GABA release is action potential independent and likely represents the tonic activation of extrasynaptic $\alpha 5 \beta \mathrm{x} \gamma 2$-type $\mathrm{GABA}_{\mathrm{A}}$ receptors on $\mathrm{GnRH}$ neurons (Brickley et al., 1996; Sim et al., 2000).

One striking difference, however, was the presence of silenttype GnRH neurons in only the juvenile mice. Experiments revealed the presence of both inward and outward rectifiers in these cells but a complete inability to fire action potentials. Although glial cells express a range of potassium channels (Bordey and Sontheimer, 2000), we believe that these recordings are not from glial cells because they did not contain GFAP transcripts and, further, were encountered only in juvenile mice. Intriguingly, preliminary work indicates that the Gn11-immortalized GnRH neurons, obtained from the nasal placode, are similarly unable to fire action potentials (Maggi et al., 2000). However, the precise nature of these interesting GnRH-expressing cells remains unknown. One intriguing speculation, however, is that they may represent the forebears of the adult type III and type IV GnRH neurons, which could be of particular importance to synchronized GnRH activity.

Our data also suggest the possibility that $\mathrm{Ca}^{2+}$ conductances may play a more prominent role in the cellular excitability of GnRH neurons in juveniles compared with adults. The TTXindependent $\mathrm{Ca}^{2+}$ spikes $(43 \%)$ and AHP conductances $(38 \%)$ were observed more frequently in juvenile GnRH neurons compared with adult GnRH cells (11 and 7\%, respectively). These slow spikes arise from the activation of T-type $\mathrm{Ca}^{2+}$ channels (Bean and McDonough, 1998) and have also been identified in the embryonically immortalized GT1 cells (Van Goor et al., 1999b). Intriguingly, embryonic GnRH neurons also exhibit clear periodic oscillations in their intracellular calcium concentrations (Terasawa et al., 1999). Together, our present data suggest that either the expression of $\mathrm{T}$ - and $\mathrm{N}$-type $\mathrm{Ca}^{2+}$ channels becomes progressively lower with postnatal development or other alterations in $\mathrm{GnRH}$ neurons make their functional presence less obvious.

\section{Conclusions}

We provide here the first detailed account of the basic membrane properties of postnatal GnRH neurons in the mouse and show that, like other neurons, they express various conductances that underlie membrane excitability. Unexpectedly, however, we have observed a marked degree of heterogeneity in the expression of functional potassium and calcium channels that play a role in determining the firing characteristics of GnRH neurons. Developmentally, the major differences between juvenile and adult GnRH neurons were those of reduced GnRH cell type heterogeneity and a more apparent role for specific calcium channels in juvenile GnRH neurons. Other neuroendocrine phenotypes such as the oxytocin and vasopressin neurons do not exhibit substantial heterogeneity in their membrane properties (Stern and Armstrong, 1995), whereas the tuberoinf undibular dopaminergic neurons exhibit only small degrees of variability (Loose et al., 1990). The apparent heterogeneity in levels of channel expression within the GnRH neuronal populations may well result from their scattered distribution and likely individual microenvironments. Precisely what impact this heterogeneity has on function is not yet clear, but the present results provide critical direct evidence for the hypothesis that the GnRH neurons develop into a functionally heterogeneous population likely involved in multiple neuronal networks. 


\section{REFERENCES}

Bean BP, McDonough SI (1998) Two for T. Neuron 20:825-828.

Bordey A, Sontheimer H (2000) Ion channel expression by astrocytes in situ: comparison of different CNS regions. Glia 30:27-38.

Bosma MM (1993) Ionic channel properties and episodic activity in isolated immortalized gonadotropin-releasing hormone $(\mathrm{GnRH})$ neurons. J Membr Biol 136:85-96.

Brickley SG, Cull-Candy SG, Farant M (1996) Development of a tonic form of synaptic inhibtion in rat cerebellar granule cells resulting from persistent activation of $\mathrm{GABA}_{\mathrm{A}}$ receptors. J Physiol (Lond) 497:753-759.

Gore AC, Wu TJ, Rosenberg JJ, Roberts JL (1996) Gonadotropinreleasing hormone and NMDA receptor gene expression and colocalization change during puberty in female rats. J Neurosci 16:5281-5289.

Hales TG, Sanderson MJ, Charles AC (1994) GABA has excitatory actions on GnRH secreting immortalized hypothalamic (GT1-7) neurons. Neuroendocrinology 59:297-308.

Halliwell JV, Adams PR (1982) Voltage-clamp analysis of muscarinic excitability in hippocampal neurons. Brain Res 250:71-92.

Hamill OP, Marty A, Neher E, Sakmann B, Sigworth FT (1981) Improved patch-clamp techniques for high resolution current recording from cell and cell-free membrane patches. Pflügers Arch 391:85-100.

Hiatt ES, Brunetta PG, Seiler GR, King JC (1992) Subgroups of luteinizing hormone-releasing hormone perikarya defined by computer analyses in the basal forebrain of intact female rats. Endocrinology 130:1030-1043.

Huguenard JK (1996) Low-threshold calcium currents in central nervous system neurons. Annu Rev Physiol 58:329-368.

Kelly MJ, Ronnekleiv OK (1994) Electrophysiological analysis of neuroendocrine neuronal activity in hypothalamic slices. Methods Neurosci 20:47-67.

Kobayashi M, Inoue T, Matsuo R, Masuda Y, Hidaka O, Kang Y, Morimoto T (1993) Role of calcium conductances on spike afterpotentials in rat trigeminal motoneurons. J Neurophysiol 77:3273-3283.

Kusano K, Fueshko S, Gainer H, Wray S (1995) Electrical and synaptic properties of embryonic luteinizing hormone-releasing hormone neurons in explant cultures. Proc Natl Acad Sci USA 92:3918-3922.

Lagrange AH, Ronnekleiv OK, Kelly MJ (1995) Estradiol-17 $\beta$ and $\mu$-opioid peptides rapidly hyperpolarize GnRH neurons: a cellular mechanism of negative feedback? Endocrinology 136:2341-2344.

Levine JE, Bauer-Dantoin AC, Besecke LM, Conaghan LA, Legan SJ, Meredith JM, Strobl FJ, Urban JH, Vogelsong KM, Wolfe AM (1991) Neuroendocrine regulation of luteinizing hormone pulse generator in the rat. Recent Prog Horm Res 47:97-153.

Loose MD, Ronnekleiv OK, Kelly MJ (1990) Membrane properties and response to opioids of identified dopamine neurons in the guinea pig hypothalamus. J Neurosci 10:3627-3634.

Maggi R, Pimpinelli F, Molteni L, Rosati B, Wanke E, Martini L (2000) The migratory activity "in vitro" of immortalized hypothalamic LHRH neurons correlates with their maturational stage and electrical activity. Eur J Neurosci 12[Suppl 11]:258.

Merchenthaler I, Lennard DE, Lopez FJ, Negro-Vilar A (1993) Neonatal imprinting predetermines the sexually dimorphic, estrogendependent expression of galanin in luteinizing hormone-releasing hormone neurons. Proc Natl Acad Sci USA 90:10479-10483.

Ojeda SR, Urbanski HF (1994) Puberty in the rat. In: The physiology of reproduction (Knobil E, Neill JD, eds), pp 363-407. New York: Raven.

Pape H-C (1996) Queer current and pacemaker: the hyperpolarizationactivated cation current in neurons. Annu Rev Physiol 58:299-327.

Pape J-R, Skynner MJ, Allen ND, Herbison AE (1999) Transgenics identifying distal $5^{\prime}$ - and $3^{\prime}$-sequences specifying gonadotropinreleasing hormone expression in adult mice. Mol Endocrinol 13:2203-2211.

Porkka-Heiskanen T, Urban JH, Turek FW, Levine JE (1994) Gene expression in a subpopulation of luteinizing hormone-releasing hormone (LHRH) neurons prior to the preovulatory gonadotropin surge. J Neurosci 14:5548-5558.

Rudy B (1988) Diversity and ubiquity of K channels. Neuroscience 25:729-749.

Schoppa NE, Westbrook GL (1999) Regulation of synaptic timing in the olfactory bulb by an A-type potassium current. Nat Neurosci 2:1106-1113.

Schwindt PC, Spain WT, Foehring RC, Stafstrom CE, Chubb MC, Crill WE (1988) Multiple potassium conductance and their functions in neurons from cat sensorimotor cortex. J Neurophysiol 59:424-449.

Silverman A, Livne I, Witkin JW (1994) The gonadotrophin-releasing hormone (GnRH), neuronal systems: immunocytochemistry and in situ hybridization. In: The physiology of reproduction (Knobil E, Neill JD, eds), pp 1683-1706. New York: Raven.

Sim JA, Allen TJG (1998) Morphological and membrane properties of rat magnocellular basal forebrain neurons maintained in culture. J Neurophysiol 80:1653-1669.

Sim JA, Skynner MJ, Pape JR, Herbison AE (2000) Late postnatal reorganization of $\mathrm{GABA}_{\mathrm{A}}$ receptor signalling in native $\mathrm{GnRH}$ neurons. Eur J Neurosci 12:3497-3504.

Simonian SX, Skynner MJ, Sieghart W, Essrich C, Luscher B, Herbison AE (2000) Role of GABA receptor $\gamma 2$ subunit in the development of the gonadotropin-releasing hormone neurons in vivo. Eur J Neurosci $12: 3488-3496$

Skynner MJ, Slater R, Sim JA, Allen ND, Herbison AE (1999a) Promoter transgenics reveal multiple gonadotropin-releasing hormone-Iexpressing cell populations of different embryological origin in mouse brain. J Neurosci 19:5955-5966.

Skynner MJ, Sim JA, Herbison AE (1999b) Detection of estrogen receptor alpha and beta messenger ribonucleic acids in adult gonadotropin-releasing hormone neurons. Endocrinology 40:5195-5201.

Spergel DJ, Kruth U, Hanley DF, Sprengel R, Seeburg PH (1999) GABA- and glutamate-activated channels in green fluorescent proteintagged gonadotropin-releasing hormone neurons in transgenic mice. J Neurosci 19:2037-2050.

Stern JE, Armstrong WE (1995) Electrophysiological differences between oxytocin and vasopressin neurons in female rats in vitro. J Physiol (Lond) 16:4861-4871.

Storm JF (1990) Potassium currents in hippocampal pyramidal cells. Prog Brain Res 83:161-187.

Suter KJ, Song WJ, Sampson TL, Wuarin JP, Saunders JT, Dudek FE, Moenter SM (2000) Genetic targeting of green fluorescent protein to gonadotropin-releasing hormone neurons: characterization of whole-cell electrophysiological properties and morphology. Endocrinology 141:412-419.

Terasawa E, Schanhofer WK, Keen KL, Luchansky L (1999) Intracellular $\mathrm{Ca}^{2+}$ oscillations in luteinizing hormone-releasing hormone neurons derived from the embryonic olfactory placode of the rhesus monkey. J Neurosci 19:5898-5909.

Van Goor F, Krsmanovic LZ, Catt KJ, Stojilkovic SS (1999a) Coordinate regulation of gonadtropin-releasing hormone neuronal firing patterns by cytosolic calcium and store depletion. Proc Natl Acad Sci USA 96:4101-4106.

Van Goor F, Krsmanovic LZ, Catt KJ, Stojilkovic SS (1999b) Control of action potential-driven calcium influx in GT1 neurons by the activation status of sodium and calcium channels. Mol Endocrinol 13:587-603.

Wang H, Hoffman GE, Smith MS (1995) Increased GnRH mRNA in the GnRH neurons expressing cFos during the proestrous LH surge. Endocrinology 136:3673-3676.

Wray S, Hoffman G (1986) Postnatal morphological changes in rat LHRH neurons correlated with sexual maturation. Neuroendocrinology 43:93-97. 